\begin{tabular}{|c|c|c|}
\hline 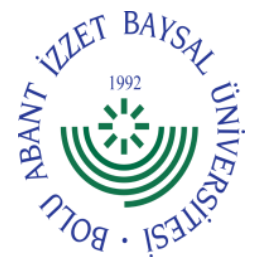 & $\begin{array}{l}\text { International Journal of Agriculture and Wildlife } \\
\qquad \text { Science } \\
\text { http://dergipark.org.tr/ijaws }\end{array}$ & 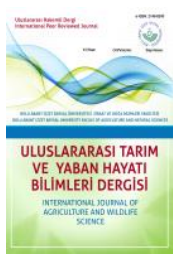 \\
\hline
\end{tabular}

Research Article

\title{
Identification of Heterodera latipons Using PCR with Sequence Characterised Amplified Region (SCAR) Primers
}

\author{
Mustafa İmren $^{1 *}, \quad$ Abdurrahman Sami Koca ${ }^{1}, \quad$ Abdelfattah Amer Dababat ${ }^{2}$ \\ ${ }^{1}$ Department of Plant Protection, Faculty of Agriculture and Natural Sciences, Bolu Abant İzzet Baysal University, Bolu, \\ Turkey \\ ${ }^{2}$ International Maize and Wheat Improvement Center (CIMMYT), Ankara, Turkey
}

Received: 15.01 .2019

Accepted: 27.03.2019

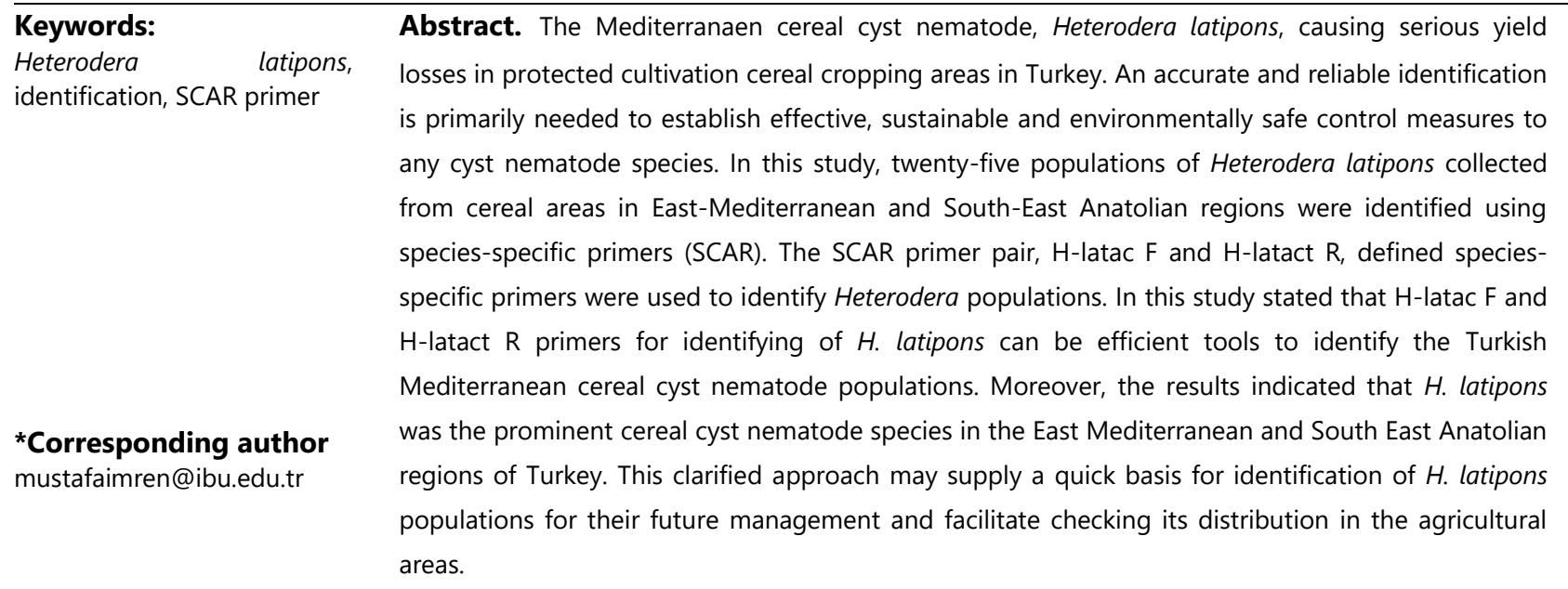

\section{Heterodera latipons' un SCAR (Sequence Characterised Amplified Region) Primer Kullanılarak Tanımlanması}

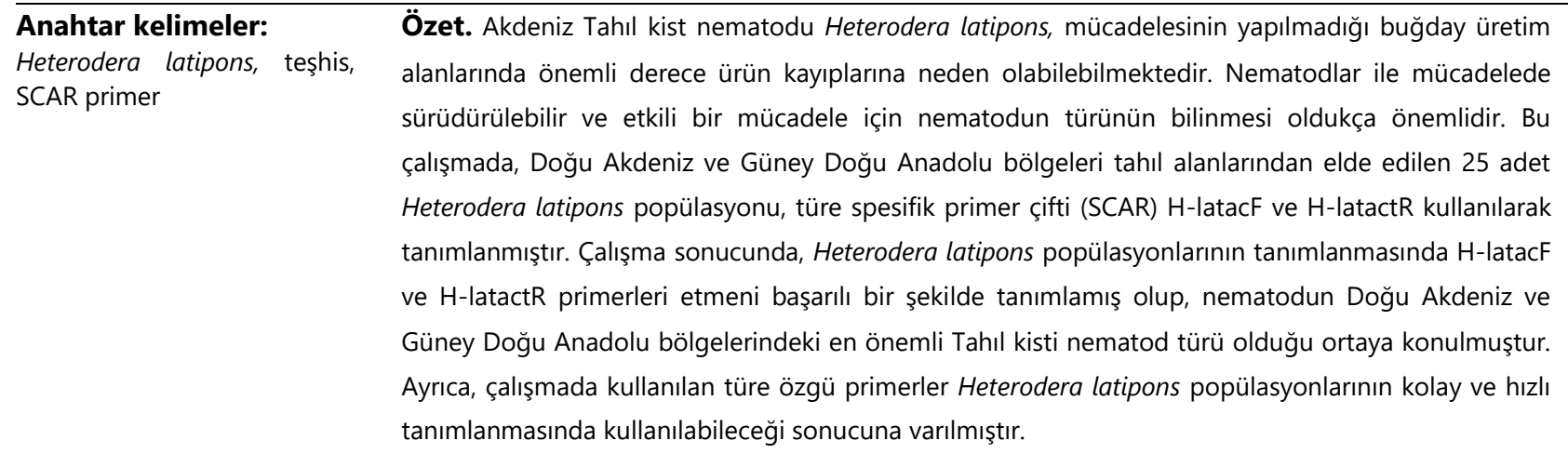




\section{INTRODUCTION}

Cereal cyst nematodes (CCN) are a group of root-feeding plant-parasitic nematodes that infect many kinds of cereals used as food crops and are known to be a major constraint to wheat production as they cause significant crop losses globally (Nicol, 2002; Dababat et al., 2014). The cereal cyst nematodes (CCN), Heterodera spp., are amongst the most economically significant phytonematodes infecting cereal in Europe, America and Asia (Cook and Noel, 2003). Twelve Heterodera spp. infecting cereal crops worldwide, of these species, $H$. avenae (Wollenweber), H. latipons (Franklin) and H. filipjevi (Madzhidov) Stone (Rivoal and Cook, 1993, McDonald and Nicol, 2005) have been found in Turkey and reported to cause significant yield losses (Imren and Elekcioğlu, 2015; Dababat et al., 2015). The Mediterranean cereal cyst nematode, Heterodera latipons, is common in the Mediterranean countries including; Turkey, Cyprus, Italy, Spain, Israel, Libya and Jordan (Franklin, 1969; Cohn and Ausher, 1973; Mor et al., 1992; Yousef and Jacob, 1994; Philis, 1995; Imren et al., 2012; 2015).

The accurate identification and quantification of nematode species is an essential step in nematode control strategies. However, correct and rapid identification of nematode species is very significant both for breeding programs and for studying their genetic and biological variability or to prevent form global spread pathogens (Blok and Powers, 2009). Heterodera spp. are extremely diverse, genetically, morphologically and biologically, and therefore, its identification is complex, problematic and time consuming using classical techniques. Moreover, its identification can be mistaken in some cases when the perineal patterns have been used as the only criterion (McDonald and Nicol, 2005). Recently, novel molecular diagnostic techniques provide clues to solve taxonomic problems associated with conventional species identification (Al-Banna et al., 2004; Szalanski et al., 1997). Ribosomal DNA analyses are commonly accepted as alternative methods including polymorphism of restriction enzyme recognition sites (PCR-RFLP), length variation and comparative sequence analysis of rDNA array such as ITS1 and ITS2 (Cherry et al., 1997; Power et al., 1997; Thiery and Mugniery, 1996). Also, the species-specific primers (SCAR) have many advantages such as highly dependable, powerful, repeatable method for studying the genetic structure of populations (Thoumi et al., 2015).

The aims of this research were to identify $H$. latipons populations obtained from wheat and barley growing areas in Adana, Kilis, Hatay, Gaziantep, Kilis, and Mardin provinces in Turkey using the species-specific primers (SCAR) from the last studies for $H$. latipons species identification in this region. These primers would be used to amplify the SCAR, enabling the straightforward, fast and reliable identification of $H$. latipons.

\section{MATERIAL AND METHOD}

\section{Nematode Sampling and Extraction}

Twenty-five $H$. latipons populations were obtained from wheat and barley fields of different localities; sixteen populations from the southeast area (Gaziantep, Kilis, and Mardin provinces) and nine population eastern mediternaen region (Adana and Hatay provinces) in Turkey (Table 1).

Table 1. Primers used in this study.

Çizelge 1. Çalıșmada kullanılan primerler.

\begin{tabular}{llll}
\hline Primer name & Sequence $\left(5^{\prime}-\mathbf{3}^{\prime}\right)$ & Using & Reference \\
\hline Hlat-actF & ATGCCATCATTATTCCTT & SCAR primer & Toumi et al., 2013 \\
Hlat-actR & ACAGAGAGTCAAATTGTG & of H. latipons & \\
\hline
\end{tabular}

Nematode samples were collected from plants showing symptoms of chlorotic, yellowing leaves, and poor growth. From each field a total of ten subsamples including soil and roots were taken by Auger at a depth of $15-20 \mathrm{~cm}$ and then the subsamples were mixed together to form a representative sample of $2 \mathrm{~kg}$. The modified sieving-decanting method (Fenwick, 1940) was used to extract cysts from soil and identified under a stereobinocular microscope (Zeiss, Jena, Germany, V20) at $12 \times$ magnification. After the extraction, cysts were stored at $4{ }^{\circ} \mathrm{C}$. Nematode specimens were obtained from wheat and barley fields in 2016.

\section{Molecular Identification of Nematode DNA extraction}

Mature females (cyst) of $H$. latipons were selected for DNA extraction. A single cyst was placed into $45 \mu \mathrm{l}$ of double distilled water $\left(\mathrm{ddH}_{2} \mathrm{O}\right)$ in an Eppendorf tube which was then crashed by using a micro homogeniser 
(Vibro Mixer). Then, the mix (40 $\mu \mathrm{l})$ were placed into a $0.2 \mathrm{ml} \mathrm{PCR}$ tube. The lysis buffer (WLB) (10 $\mu \mathrm{l})$ and Proteinase $\mathrm{K}(20 \mathrm{mg} / \mathrm{ml})$ were added to the mixture and incubated at $80^{\circ} \mathrm{C}$ for at least $10 \mathrm{~min}$. Incubation was performed at $65^{\circ} \mathrm{C}$ for $1 \mathrm{~h}$ and $95^{\circ} \mathrm{C}$ for $10 \mathrm{~min}$ in a thermocycler. Finally, the product was centrifuged at 14000 rpm for $1 \mathrm{~min}$ and stored at $-20^{\circ} \mathrm{C}$ as per (Maafi et al., 2003; Waeyenberge et al., 2009).

\section{PCR amplification using SCAR primer}

The species-specific forward primer (Hlat-act F) and the reverse primer (Hlat-act R) (Table 2) (Toumi et al., 2013) were used in the identification of $H$. latipons. The species-specific forward primers Hlac-actiF and reverse Hlac-actiF were designed based on the variable region in the alignment of the 28S rRNA expansion domains.

Table 2. List of identified Heterodera latipons sampled from wheat and barley fields in Agro-ecological regions of Turkey. Çizelge 2. Türkiye'nin Agro-ekolojik bölgelerinde örnekleme yapılan buğday ve arpa alanlarından tanımlanmış Heterodera latipons listesi.

\begin{tabular}{|c|c|c|c|c|}
\hline No & Province & District & Location & Species \\
\hline 1 & Adana & Sarıçam & Giriş Gediği & H. latipons \\
\hline 2 & Adana & Sarıçam & Kepeztepe & H. latipons \\
\hline 3 & Adana & Sarıçam & Dutluca & H. latipons \\
\hline 4 & Adana & Sarıçam & Tülüler & H. latipons \\
\hline 5 & Hatay & Kırıkhan & Kurtlusoğuksu & H. latipons \\
\hline 6 & Hatay & Kırıkhan & Merkez -I & H. latipons \\
\hline 7 & Hatay & Kırıkhan & Merkez -II & H. latipons \\
\hline 8 & Hatay & Reyhanlı & Karakaya & H. latipons \\
\hline 9 & Hatay & Reyhanlı & Müşrüfe & H. latipons \\
\hline 10 & Gaziantep & Karkamış & Türkyurdu & H. latipons \\
\hline 11 & Gaziantep & Karkamış & Akçaköy-I & H. latipons \\
\hline 12 & Gaziantep & Karkamış & Akçaköy-II & H. latipons \\
\hline 13 & Gaziantep & Karkamış & Arıkdere-I & H. latipons \\
\hline 14 & Gaziantep & Karkamış & Arıkdere-II & H. latipons \\
\hline 15 & Kilis & Musabeyli & Haydarlar & H. latipons \\
\hline 16 & Kilis & Musabeyli & Deliçay & H. latipons \\
\hline 17 & Kilis & Musabeyli & Besenli & H. latipons \\
\hline 18 & Kilis & Merkez & Acar & H. latipons \\
\hline 19 & Kilis & Merkez & Karaöner & H. latipons \\
\hline 20 & Kilis & Merkez & Yığmatepe & H. latipons \\
\hline 21 & Kilis & Elbeyli & Doğanlı & H. latipons \\
\hline 22 & Mardin & Nusaybin & Merkez & H. latipons \\
\hline 23 & Mardin & Nusaybin & Cizre Yolu & H. latipons \\
\hline 24 & Mardin & Nusaybin & Yolindi & H. latipons \\
\hline 25 & Mardin & Kızıltepe & Güneyli & H. latipons \\
\hline
\end{tabular}

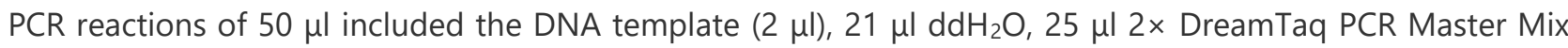
(Fermentas Life Sciences, Germany), and $1 \mu \mathrm{M}$ of each of the primers, Hlac-actiF and Hlac-actiR. PCR amplification was performed in a thermocycler (Bio-Rad) as follows: $95^{\circ} \mathrm{C}$ for 5 mins followed by 30 cycles of 30 $\mathrm{s}$ at $94{ }^{\circ} \mathrm{C}, 45 \mathrm{~s}$ at $50^{\circ} \mathrm{C}$ and $45 \mathrm{~s}$, with a final extension at $72{ }^{\circ} \mathrm{C}$ for $10 \mathrm{~min}$ (Toumi et al., 2013). Products of PCR were separated in $1 \%$ standard agarose gels mixed with safe stain. Molecular size was estimated by a $100 \mathrm{bp}$ DNA ladder (Fermentase). The pattern of the band was imaged under UV light (Figure 1). 


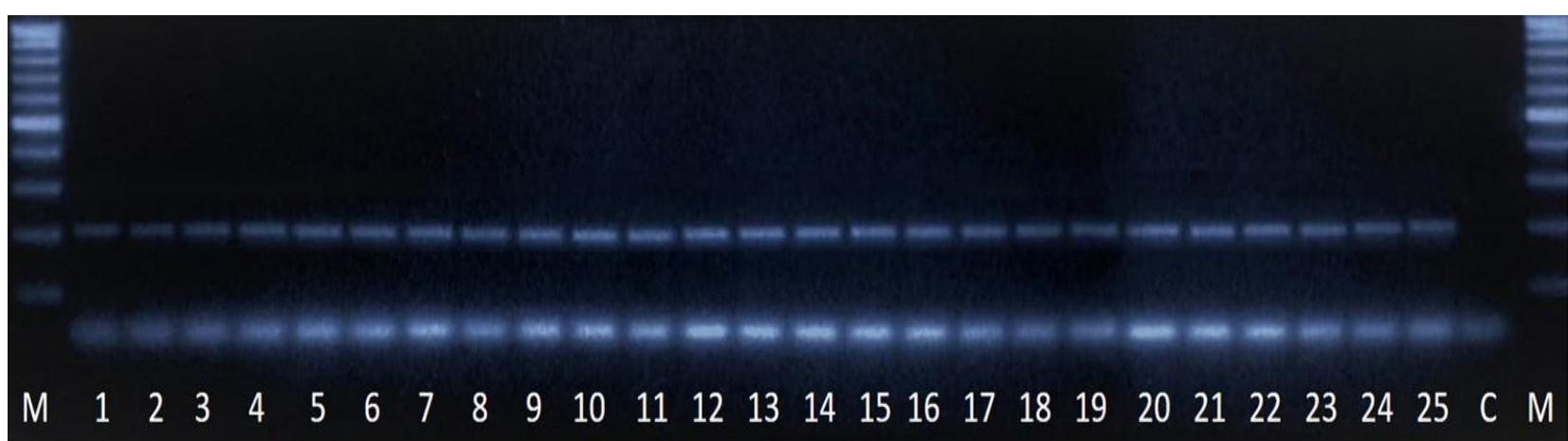

Figure 1. Agorase gel image of PCR product of Heterodera latipons using SCAR primers. M: 100 bp DNA ladder, C: Negative control.

Şekil 1. SCAR primerleri kullanarak Heterodera latipons'un PCR ürününün agoraz jel görüntüsü.

\section{RESULTS AND DISCUSSION}

The cereal cyst nematode species are morphologically very similar to each other and identification them to the species level is difficult (Hando, 2002). Moreover, more than one cereal cyst nematode species are sometimes can be found together on the root of the same plant. Hence, fast and precise identification of cyst nematode is needed for choosing the appropriate management strategy especially by the breeding programs (Smiley et al., 2004). Description of cyst nematode populations from around the world is essential to understand the morphological, biochemical and molecular variability within a species and to recognize stable characters for their diagnosis (Rumpenhorst, 1996; Subbotin et al., 2010). Among the molecular identification techniques, the species-specific primers (SCAR) is an correct and rapid identification methods of cereal cyst nematode species. So far, only two publications stated the development and use of species-specific primers for molecular identification of Heterodera species, H. latipons (Toumi et al., 2013). The species-specific primers were developed by Toumi et al. (2013) generate bands at 204 bp. The result of this study confirmed the specificity of the primer sets.

Heterodera latipons populations were identified using the species-specific (SCAR) primers (Toumi et al., 2013) in this study. Hlac-actiF and Hlac-actiR primers amplified a unique PCR product from its respective aim and did not produce an applicant from other Heterodera species. The H. latipons species-specific primers PCR (HlacactiF and Hlac-actiR) amplified a band of 204 bp for 25 samples (Figure 1). Moreover, these primers produced no band of DNA extracted from the other two cereal cyst nematode species; $H$. avenae and $H$. filipjevi (Figure 1 ). Twenty-five cyst nematode populations were molecularly identified as $H$. latipons. Our results showed agreement with earlier studies carried out by Toumi et al. (2013) who reported that Hlac-actiF and Hlac-actiR primers amplified a PCR product which is unique product which was not produced by other Heterodera species. Additionally, actin gene amplification and nematode (cyts) amplicated product were very much similar to each other. This assay revealed that the amplification of DNA with conserved actin gene primers from all studied samples of $H$. latipons confirms the reliability of PCR test in the present study.

Amplification of the actin gene regions with the current primers was successful for the studied $H$. latipons populations in the present study. This assay indicated that preserved actin gene primers amplified DNA from all individuals of the $H$. latipons populations, therefore confirming the overall reliability of the PCR for a sample tested. However, due to rDNA repeat polymorphism within the species cause difficulty to make species-specific primers (Rivoal et al., 2003) and for this reason, we researched an alternative non-multi-copy DNA region such as the actin gene. Although this gene has been researched before (Matthews et al., 2004; Tytgat et al., 2004; Kovaleva et al., 2005; Mundo-Ocampo et al., 2008), it has never been used for identification objectives. In this work, we report on the development of a species-specific primer for $\mathrm{H}$. latipons based on actin sequences.

\section{CONCLUSION}

The CCN species, $H$. avenae and $H$. latipons which cause serious yield losses in protected cereal cropping areas in Eastern Mediterranean and South East Anatolian regions of Turkey, were identified using speciesspecific primers in this study. Primers optimized successfully resulted in amplification of DNA obtained from all the nematode sources including, juveniles and females. The primer sets were used in our studies to identify of cereal cyst nematode. 


\section{ACKNOWLEDGMENT}

The authors acknowledge the Scientific and Technological Research Council of Turkey (TUBITAK) to provide the fund under project no $115 \mathrm{R} 006$ for this study.

\section{REFERENCES}

Al-Banna, L., Ploeg, A. T., Williamson, V. M., \& Kaloshian, I. (2004). Discrimination of six pratylenchus species using PCR and species-specific primers. Journal of Nematology, 36(2), 142-146.

Blok, V. C., \& Powers, T. O. (2009). Biochemical and molecular identification. In R. N. Perry, M. Moens \& J. Starr (Eds.), RootKnot Nematodes (pp 98-112). Lincoln: CABI.

Cherry, T., Szalanski, A. L., Todd, T. C., \& Powers, T. O. (1997). The internal transcribed spacer region of Belonolaimus (Nemata: Belonolaimidae). Journal of Nematology, 29, 21-29.

Cook, R., \& Noel, G. R. (2002). Cyst Nematodes: Globodera and Heterodera species. In J. L. Star, R. Cook \& J. Bridge (Eds.), Plant Resistance to Parasitic Nematodes (pp. 71-105). CAB International.

Cohn, E., \& Ausher, R. (1973). Longidorus cohni and Heterodera latipons economic nematode pest of oat Israil. Plant Disease Report, 57, 53-54.

Dababat, A. A., Orakcı, G. E., Toktay, H., Imren, M., Akın, B., Braun, HJ., Dreisigacker, S., Elekcioglu, I. H., \& Morgunov, A. (2014). Resistance of winter wheat to Heterodera filipjevi in Turkey. Turkish Journal of Agriculture and Forestry, 38, 180186.

Dababat, A. A., Imren, M., Orakci, E. G., Ashrafi, S., Yavuzaslanoglu, E., Toktay, H., Pariyar, S., Elekcioğlu, I. H., Morgounov, A., \& Mekete T. (2015). The importance and management strategies of cereal cyst nematodes, Heterodera spp., in Turkey. Euphytica, 202, 173-188.

Fenwick, D. W. (1940). Methods for the recovery and counting of cysts of $H$. schachtii from soil. Journal of Helminthology, 18, 155-172.

Franklin, M. T. (1969). Heterodera latipons n. sp., a cereal cyst nematode from the Mediterranean region. Nematologica, 15, 535-542.

Hando, Z. A. (2002). A key compendium to species of the Heterodera avenae group (Nematode: Heteroderidae). Journal of Nematology, 34, 250-262.

Imren, M., Toktay, H., Özarslandan, A., Nicol, J. M., \& Elekcioglu, i. H. (2012). Güneydoğu Anadolu Bölgesi tahıl alanlarında tahıl kist nematodu, Heterodera avenae group türlerinin belirlenmesi. Türkiye Entomoloji Dergisi, 36(2), 265-275.

Imren, M., \& Elekcioğlu, I. H. (2015). Effect of cereal cyst nematode Heterodera avenae (Tylenchida: Heteroderidae) on yield of some spring wheat varieties in Adana Province, Turkey. Turkish Journal of Agriculture and Forestry, 38(6), 820-823.

Imren, M., Waeyenberge, L., Viaene, N., Elekcioğlu, I. H., \& Dababat, A. A. (2015). Morphological and molecular identification of cereal cyst nematodes from the eastern Mediterranean region of Turkey. Turkish Journal of Agriculture and Forestry, 39, 91-98.

Kovaleva, E. S., Subbotin, A. S., Edward, P. M., \& Chitwood, D. (2005). Molecular characterization of the actin gene from cyst nematodes in comparison with those from other nematodes. Comparative Parasitology, 72(1), 39-50.

Maafi, Z. T., Subbotin, S. A., \& Moens, M. (2003). Molecular identification of cyst-forming nematodes (Heteroderidae) from Iran and a phylogeny based on ITS-rDNA sequences. Nematology, 5(1), 99-111.

McDonald, A. H., \& Nicol, J. M. (2005). Nematode parasites of cereals. In M. Luc, R. A. Sikora \& J. Bridge (Eds.). Plant Parasitic Nematodes in Subtropical and Tropical Agriculture (pp. 131-191) CAB International.

Mundo-Ocampo, M., Troccoli, A., Subbotin, S. A., Del Cid, J., Baldwin, J. G., \& Inserra, R. N. (2008). Synonymy of Afenestrata with Heterodera supported by phylogenetics with molecular and morphological characterisation of $H$. koreana comb. $\mathrm{n}$. and H. orientalis comb. n. (Tylenchida: Heteroderidae). Nematology, 10(5), 611-632.

Mor, M., Cohn, E., \& Spiegel, Y. (1992). Phenology, pathogenicity and pathotypes of cereal cyst nematodes, Heterodera avenae and H. latipons (Nematoda: Heteroderidae) in Israel. Nematologica, 38, 494-501.

Nicol, J. M., Rivoal, R., Bolat, N., Aktas, H., Braun, H., Mergoum, J. M., Yildirim, A. F., Bagci, A., Elekcioglu, I. H., \& Yahyaoui, A. (2002). The frequency and diversity of the cyst and lesion nematodes on wheat in the Turkish central Anatolian plateau. Nematology, 4, 272.

Philis, J. (1995). An updated list of plant parasitic nematodes from Cyprus and their economic importance. Nematologia Mediterranea, 23, 307-314.

Powers, T. O., Todd, T. C., Burnell, A. M., Murray, P. C. B., Fleming, C. C., Szalanski, A. L., Adams, B. A., \& Harris, T. S. (1997). The internal transcribed spacer region as a taxonomic marker for nematodes. Journal of Nematology, 29, 441-450.

Rivoal, R., \& Cook, R. (1993). Nematode pests of cereals. In K. Evans, D. L. Trudgill \& J. M. Webster (Eds.), Plant Parasitic Nematodes in Temperate Agriculture (pp. 259-303). CAB International: Wallingford, United Kingdom.

Rivoal, R., Valette, S., Bekal, S., Gauthier, J. P. \& Yahyaoui, A. (2003). Genetic and phenotypic diversity in the graminaceous cyst nematode complex, inferred from PCR-RFLP of ribosomal DNA and morphometric analysis. European Journal of Plant Pathology, 109, 227-241.

Rumpenhorst, H. J., Elekçioğlu, I. H., Sturhan, D., Öztürk, G., \& Enneli, S. (1996). The cereal cyst nematode Heterodera filipjevi (Madzhidov) in Turkey. Nematologia Mediterránea, 24, 135-138. 
Smiley, R. W., Gourlie, J. A., Whittaker, R. G., Easley, S. A., \& Kidwell, K. K. (2004). Economic impact of Hessian fly (Diptera: Cecidomyiidae) on spring wheat in Oregon and additive yield losses with Fusarium crown rot and lesion nematode. Journal of Economic Entomology, 97(2), 397-408.

Subbotin, S. A., Mundo-Ocampo, M., \& Baldwin, J. G. (2010). Systematics of cyst nematodes (Nematode: Heteroderinae) nematology monographs and perspectives $8 A$. In: Biology and Evolution. Brill Leiden-Boston.

Szalanski, A. L., Sui, D. D., Harris, T. S., \& Powers, T. O. (1997). Identification of cyst nematodes of agronomic and regulatory concern with PCR-RFLP of ITS1. Journal of Nematology, 29, 255-267.

Toumi, F., Waeyenberge, L., Viaene, N., Dababat, A. A., Nicol, J. M., Ogbonnaya, F., \& Moens, M. (2013). Development of two species-specific primer sets to detect the cereal cyst nematodes Heterodera avenae and Heterodera filipjevi. European Journal of Plant Pathology, 136(3), 613-624.

Toumi, F., Waeyenberge, L., Viaene, N., Dababat, A. A., Nicol, J. M., Ogbonnaya, F. C., \& Moens, M. (2015). Development of qPCR assays for quantitative detection of Heterodera avenae and H. latipons. European Journal of Plant Pathology, 143(2), 305-316.

Tytgat, T., Vanholme, B., \& De Meutter, J. (2004). new class of ubiquitin extension proteins secreted by the dorsal pharyngeal gland in plant parasitic cyst nematodes. Molecular Plant-Microbe Interactions, 17, 846-852.

Yousef, D. M., \& Jacob, J. J. S. (1994). A nematode survey of vegetable crops and some orchards in the ghour of Jordan. Journal of Nematologia Mediterranea, 22, 11-15.

Waeyenberge, L., Viaene, N., Subbotin, S. A., \& Moens, M. (2009). Molecular Identification of Heterodera spp., an Overview of Fifteen Years of Research. Cereal Cyst Nematodes: Status, Research and Outlook. In Proceedings of the First Workshop of The International Cereal Cyst Nematode Initiative, 21, 109-11. 